\title{
Use of Urban Green Spaces in the Context of Lifestyle Changes during the COVID-19 Pandemic in Tokyo
}

\author{
Takahiro Yamazaki $^{1,2, * \mathbb{D}}$, Akiko Iida ${ }^{1}$, Kimihiro Hino ${ }^{1} \mathbb{D}$, Akito Murayama $^{1}, \mathrm{U}_{\text {Hiroi }}{ }^{1}$, Toru Terada $^{3}$, \\ Hideki Koizumi ${ }^{1}$ (D) and Makoto Yokohari ${ }^{1}$
}

1 Department of Urban Engineering, School of Engineering, The University of Tokyo, Tokyo 113-8656, Japan; iida@epd.t.u-tokyo.ac.jp (A.I.); hino@ua.t.u-tokyo.ac.jp (K.H.); murayama@up.t.u-tokyo.ac.jp (A.M.); hiroi@city.t.u-tokyo.ac.jp (U.H.); hide@cd.t.u-tokyo.ac.jp (H.K.); myoko@k.u-tokyo.ac.jp (M.Y.)

2 Department of Environmental Design, School of Arts and Design, Kobe Design University, Hyogo 651-2196, Japan

3 Department of Natural Environmental Studies, Graduate School of Frontier Sciences, The University of Tokyo, Chiba 277-8563, Japan; terada@k.u-tokyo.ac.jp

* Correspondence: yamazaki-t@kobe-du.ac.jp; Tel.: +81-90-2077-3594

Citation: Yamazaki, T.; Iida, A.; Hino, K.; Murayama, A.; Hiroi, U.; Terada,

T.; Koizumi, H.; Yokohari, M. Use of Urban Green Spaces in the Context of Lifestyle Changes during the COVID-19 Pandemic in Tokyo. Sustainability 2021, 13, 9817. https:// doi.org/10.3390/su13179817

Academic Editor: Francesca Poggi

Received: 12 August 2021

Accepted: 27 August 2021

Published: 1 September 2021

Publisher's Note: MDPI stays neutral with regard to jurisdictional claims in published maps and institutional affiliations.

Copyright: (c) 2021 by the authors. Licensee MDPI, Basel, Switzerland. This article is an open access article distributed under the terms and conditions of the Creative Commons Attribution (CC BY) license (https:/ / creativecommons.org/licenses/by/ $4.0 /)$.

\begin{abstract}
The coronavirus disease 2019 (COVID-19) pandemic of 2020 drastically changed urban lifestyles. Workers were forced to minimize commuting to their workplaces, older adults were banned from using meeting facilities, and children were prohibited from going to school. The consequent lack of exercise, accumulated stress, and reduced well-being are likely to have become problems, which may be improved by using urban green spaces (UGS). This study clarified the characteristics of users of UGS in Tokyo during the COVID-19 pandemic, focusing on telecommuters, older adults, and families with children. An online questionnaire survey was conducted among Tokyo residents, and 3085 responses were obtained. A binomial logistic regression analysis was conducted with the use and evaluation of UGS as the objective variables. The results showed that older adults and families with children who had been using UGS before the pandemic and telecommuters who newly started using UGS during the pandemic used UGS differently. Older adults and families with children tended to use small parks and appreciated human connections. Telecommuters often used greenways, temples, and shrines, valuing stress-reducing functions. Given that a changing lifestyle brings new UGS users new preferences, urban planners should consider that UGS require change with the time.
\end{abstract}

Keywords: telecommuter; teleworker; older adults; families with children; urban parks; greenway; urban forest; temple and shrine; coronavirus; Japan; Asian megacity

\section{Introduction}

\subsection{Background and Objectives}

On 30 January 2020, the World Health Organization (WHO) declared an international public health emergency due to the coronavirus disease 2019 (COVID-19) pandemic [1] Governments around the world implemented quarantine measures to minimize the chances of human-to-human contact [2]. Workers who commuted to the central business district almost every day were strongly urged to switch to telecommuting. Most public meeting facilities frequented by older adults, and schools attended by children were temporarily closed. With the exception of essential workers, city dwellers were forced to stay home, regardless of their lifestyle. In cities around the world, lifestyles changed drastically.

Tokyo, Japan, has one of the largest populations in the world, with people living together in a very dense environment. Thus, the governor of Tokyo encouraged behavior that avoids the 3Cs (closed spaces, crowded places, and close-contact settings) to reduce the spread of the first wave of COVID-19 [3]. For example, trains in Tokyo are very congested compared with other cities due to the city's urban structure, with functions 
concentrated in the city center; therefore, to avoid the 3Cs on trains, the governor set a goal of reducing the number of people commuting to work by $70 \%$. To achieve this goal, many companies had to adopt telecommuting systems [4]. Even before the pandemic, Tokyo had already been regarded as a workaholic city. Working hours and commuting time were long, and time spent on leisure was short, resulting in a work-life balance that had been rated poor compared to cities in other countries [5]. Therefore, the rapid spread of telecommuting due to the pandemic should have resulted in a drastic shift in work styles [6]. The transformation of telecommuting as a common work style option is also expected to contribute to an improved work-life balance in Tokyo. Another characteristic of Tokyo is its high aging rate. At 51\%, Japan has the world's highest percentage of older adults aged 65 and above as a percentage of its population aged 20 and over, as of 2019 [7]. The spread of COVID-19 among older adults, who are at a high risk of contracting severe disease, would have pressured the limited healthcare supply system [8]. Accordingly, the closing of public meeting facilities that tended to be frequented by older adults was undertaken as a priority quarantine measure for the first wave of COVID-19. The other major quarantine measure, as implemented in other countries, was the closure of educational institutions from nursery schools to universities [9]. Hence, workers, older adults, and children and their families had to make drastic changes in their lifestyles.

Urban green spaces (UGS) are likely to be valuable places for individuals who are virtually forced to live in and around their homes. These places allow people to exercise and rest without worrying about the $3 \mathrm{Cs}$, whereas refraining from going out causes problems of lack of exercise and stress accumulation. In fact, the number of people using UGS seems to have increased during the pandemic [10], except in countries that had strong lockdowns in place during the pandemic [11]. In megacities, in particular, houses, gardens, and balconies are usually small. A survey in Europe and South America found that city residents who spent the lockdown period in smaller houses had a lower sense of well-being [12]. It seems that UGS were essential places of exercise and rest for megacity residents during the pandemic. However, it has been reported that there are many people whose use of UGS decreases as well as those whose use of UGS increases, even if the use of UGS is not restricted [13]. Therefore, it is important to understand how and by whom UGS were used and valued by megacity residents during the COVID-19 pandemic to enhance urban resilience.

The purpose of this study was to clarify the relationship between individuals' personal characteristics and the use of UGS during the COVID-19 pandemic in Tokyo. Specifically, this study focused on telecommuters, older adults, and families with children, whose lifestyle may have been drastically changed due to the COVID-19 pandemic. The analysis focused on whether UGS were used, based on each type of UGS, and how users evaluated and perceived the use of UGS. Based on the results, this study discusses points that should be considered for planning UGS in the post-COVID-19 society.

\subsection{Previous Surveys}

Many studies have discussed the health and well-being effects of UGS [14-21]. BedimoRung et al. (2005) proposed a model of the process by which UGS can properly exert these effects [22]. According to the model, two factors influence the improvement of health and well-being through the use of UGS: the characteristics of the user and the characteristics of the UGS. In other words, considering user characteristics is as important as considering spatial characteristics if urban planners want to increase the benefits of UGS.

Several studies have analyzed the relationship between UGS and user characteristics $[23,24]$. Age is frequently discussed as a personal attribute that strongly influences the use of UGS. Older adults [25-28] and younger people [29-31] tend to use UGS more. Among young people, families with children have particularly high rates of using UGS [26-29]. The influence of gender has also been noted. Depending on the study, there appear to be higher rates of utilization for males [29,32] as well as females [33]. Some studies have also mentioned the influence of race [29]. Moreover, several studies have pointed 
to the impact of living characteristics on the use of UGS. Those with roommates $[29,30]$, dogs [26], and those living in the suburbs [30] have been found to be more likely to use UGS. One study has discussed work styles in relation to using UGS. It appears that people use UGS more when they are not working full-time [29]. Given the increase in the number of telecommuters due to the COVID-19 pandemic, it is important to understand how these changes in work style have affected the use of UGS.

Several pioneering studies have targeted the use of UGS during the COVID-19 pandemic. Geng et al. (2021) analyzed the trends and determinants of UGS visitation by country using the Google COVID-19 Community Mobility Report for 48 countries from 16 February to 26 May, 2020 [11]. Ugolini et al. (2020) conducted an online survey between 12 April and 4 May, 2020, in six countries in Europe and the Middle East to compare the use and perception of UGS before and after the pandemic by country [34]. These two international comparative studies concluded that trends in the use of UGS were largely influenced by the stringency of government quarantine policies.

In addition to global studies, some case studies have been conducted on specific cities or nations to examine trends in the use of UGS. Venter et al. (2020) compared the number of users of UGS before and during the pandemic through mobile data analysis in the city of Oslo, Norway, and concluded that the number of users of UGS increased by $291 \%$ during the pandemic [10]. Meanwhile, Berdejo-Espinola et al. (2021) showed that not all city residents increased their frequency of UGS use. A questionnaire examining the frequency of UGS use in Brisbane, Australia, during and before the country's periods of mobility restrictions showed that $26 \%$ of respondents used UGS less, while $36 \%$ used them more. The study shows that the frequency of use tended to decrease with age [13]. Xie et al. (2020) conducted an online survey of park users in Chengdu, China, from 1 April to 5 April 2020, to analyze the health and well-being benefits of UGS. It appears that users of UGS were able to improve their physical health and meet their social interaction needs during the pandemic [35]. The results of an online survey conducted in Mexico City, Mexico by Huerta and Utomo (2021) similarly showed that the use of UGS during the pandemic contributed to improved subjective well-being among individuals [36]. Poortinga et al. (2021) analyzed a Welsh government survey on the health of the UK Welsh population and found that the use of UGS contributed to people's improved subjective well-being and sense of health during the pandemic, regardless of age or gender [37].

Three studies of the Tokyo metropolitan area during the pandemic mention UGS use. Lu et al. (2021) analyzed online posts on the photo-sharing social media networking service Instagram from four Asian cities, including Tokyo, and found that people preferred parks that were close to the city center, large in size, and rich in nature [38]. Soga et al. (2020) conducted an online survey in Tokyo and found that people were more likely to use green spaces if they had a view of greenery from their homes [39]. Hino and Asami (2021) analyzed the relationship between the number of steps taken in a day and the location of residence in Yokohama City, which is within the Tokyo metropolitan area, and compared results during and before the pandemic [40]. Consequently, while the number of steps was found to have decreased significantly in densely populated areas, the number of steps did not decrease as much when the distance to a large UGS was close. For older women in particular, the decrease in steps was found to be mitigated when they lived near a large park. These studies suggest that the use of UGS had been important in Tokyo during the pandemic. However, there have been limited studies on UGS during the pandemic that take into account the characteristics of the users, even though their lifestyles have been drastically changed by the COVID-19 pandemic.

\section{Methods}

\subsection{Characteristics of the Survey Area and the Pandemic Period}

In Japan, a state of emergency was declared on 7 April, 2020, in response to the initial wave of COVID-19. The declaration of a state of emergency is the most severe measure that 
the Japanese government can take under the law. In Tokyo, the state of emergency was in effect for about 1.5 months until 25 May, when the medical system began to improve.

Residents of Tokyo during this emergency period were asked by the government to voluntarily refrain from leaving their homes unnecessarily [41]. For example, they were asked to reduce the number of times they commuted to work or school and refrain from holding or participating in events. However, there was no obligation to record one's outings using healthcare mobile applications to enable contact tracing, nor was there any penalty for going out. In addition, the government informed that "people can go out when it is necessary to maintain their lives, such as going to medical institutions, shopping for daily necessities, going to essential workplaces, and walking or jogging to maintain their health" [42]. In other words, Japanese quarantine measures were not as strict as lockdowns in Western countries [41,43]. Therefore, UGS around the home, which are easy to use and avoid the 3Cs, would have been valuable places for exercise and rest during the emergency period. In fact, most of the UGS in Tokyo, whether publicly or privately owned, could be used during the emergency period as long as physical distancing was maintained. However, parking lots and stands were closed, and some gated UGS, such as gardens and university campuses were closed as well. During this period, Tokyo had only one rainy day per week, and the maximum temperature ranged from $15{ }^{\circ} \mathrm{C}$ to $25^{\circ} \mathrm{C}$, making it easy to spend time outdoors.

Focusing on UGS in Tokyo, there is a lack of parks owned by the local government; however, there is a relative abundance of various types of UGS owned by individuals and organizations. Urban parks are about $5.7 \mathrm{~m}^{2}$ per capita as of 2020 [44], which is a very low ratio when compared to that of other large cities. However, while the number of urban parks may be insufficient, privately owned UGS exist to a certain extent in Tokyo. For example, there are 4327 temple and shrine sites in Tokyo [45], compared to 8287 urban parks [46].

\subsection{Study Questionnaire}

A questionnaire survey was conducted using the platform provided by Macromill, Inc. (Tokyo, Japan), an online research company. A total of 3096 people aged 20 and above living in Tokyo responded to the questionnaire. The number of respondents was adjusted while recruiting so that they would be evenly distributed across age groups (those in their 20s, 30s, 40s, 50s, 60s, and 70s and above) and residing areas (Tokyo special wards and Tama suburban cities). The survey was conducted between 4 June and 8 June 2020, after the end of the first declaration of state of emergency by the national government.

The questions in the questionnaire survey comprised three main categories. The first category included questions on personal information, such as gender, age, co-residents, residential area, work style during the emergency period, and changes in work hours during the emergency period. The second set of questions captured the use of UGS. For each of the six types of UGS (small parks and plazas, large parks and plazas, greenways and riverbeds, urban forests, temple and shrine grounds, and urban farmlands) (Figure 1), the survey asked whether the respondents used them, and whether they had been using those UGS only recently, i.e., were new users of the UGS. The third set of questions focused on the evaluations and perceptions of the users of UGS. The following eight items were assessed using a five-point scale ('strongly agree', 'agree', 'neutral', 'disagree', and 'strongly disagree'): I felt satisfied with exercising and resting in the UGS; I felt relieved of anxiety and stress; I felt less lonely; I felt connected to others in a relaxed way; I was able to maintain a sufficient physical distance in the UGS; I was able to use the UGS without worrying about the eyes around me; It was an opportunity for me to become aware of the existence of nature around me that I had not noticed before; It was an opportunity for me to become aware of the good qualities of the area where I live. 

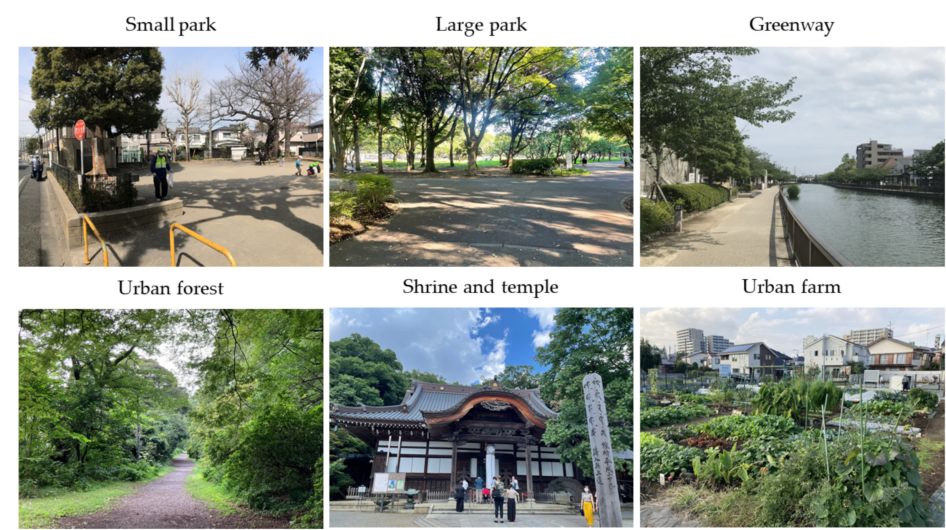

Urban farm

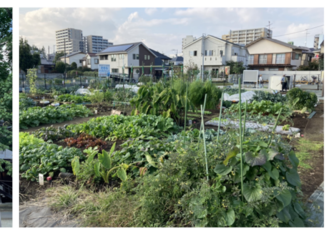

Figure 1. Urban green space type in Tokyo.

\subsection{Statistical Analysis Methods}

A binomial logistic regression analysis was conducted using three models (Table A1). Model 1 was used to determine whether UGS were used during the emergency period and whether there were new users of UGS. Model 2 determined whether UGS were used based on the type of UGS. Model 3 focused on the evaluations and perceptions of the use of UGS. In Model 3, responses on a five-point scale were categorized into binary variables with " 1 " for 'strongly agree' or 'agree' and " 0 " for other options.

The explanatory variables were respondents' personal characteristics. The main target groups were telecommuters, older adults, and families with children, whose lifestyles are expected to have been significantly affected by the pandemic. As control factors, the characteristics of the users of UGS, which have been pointed out in previous studies, were added (Table A2); these characteristics were: being male, having a roommate, living in the suburbs, and owning a dog. In addition, a previous study has discussed the relationship between full-time work and use of UGS [29]. Given the strong influence of the pandemic on work hours, we added non-workers and reduced worktime as control factors. Nine explanatory variables were used (Table A3). According to Peduzzi et al. (1996), the event per variables should be less than 10 [47]. For this reason, urban farmland (2F) with less than 90 respondents was excluded from the regression analysis in this study.

A sample of 3085 valid responses was obtained by selecting those who responded to all the variables used in the analysis. The significance level was set at $p<0.05$. $\mathrm{R}$ version 4.0.2 was used for analysis.

\subsection{Ethical Considerations}

This survey underwent an ethical review by the University of Tokyo, and preparations were made to ensure that the respondents are given enough consideration (approval number: KE20-8). Only those researchers who had completed the University of Tokyo's ethics course were involved in the storing and analyzing of data. All survey respondents consented to participate in Macromill's anonymous online survey. There was a financial incentive for respondents. All respondents understood the purpose of the survey and were informed of their right to withdraw anytime during the survey.

\section{Results}

\subsection{General Information of the Respondents}

The explanatory variables generated from the personal attributes of the 3085 respondents revealed that telecommuters, older adults, and families with children made up 37\%, $23 \%$, and $14 \%$ of the respondents, respectively. In addition, $53 \%$ of the respondents were male. In terms of housing, 75\% lived with someone, and 6\% owned a dog (Table A3).

While $37 \%$ of the respondents were telecommuters, $30 \%$ were workers who commuted physically, and the remaining 33\% did not work. Among the telecommuters, $90 \%$ were first-time home workers during the emergency period. Approximately $60 \%$ of the telecom- 
muters did not commute at all, while approximately $40 \%$ commuted a few days a week. During the emergency period, 34\% of telecommuters and 39\% of commuters worked fewer hours than usual (Table A4).

\subsection{General Results}

This section summarizes the simple tabulation of the results of the questionnaire responses that were treated as objective variables in Models 1 through 3 (Table 1). First, 46\% of the respondents used UGS. During the emergency period, the government allowed outdoor exercise, but less than half of the respondents actually used UGS. Moreover, $10 \%$ of respondents started using UGS during the emergency period. In this sense, the pandemic may have been an opportunity for them to use UGS that they had not used recently. Next, focusing on the type of UGS used, most people used greenways and riverbeds (30\%), followed by small parks (24\%) and large parks (19\%). Publicly-owned UGS were the most commonly used; however, there were also a certain number of users of temple and shrine land (9\%), urban forest land $(8 \%)$, and urban farmland $(2 \%)$, most of which are privately owned.

Table 1. Use of UGS by groups.

\begin{tabular}{|c|c|c|c|c|c|c|c|c|c|}
\hline & & \multicolumn{2}{|c|}{ Total } & \multicolumn{2}{|c|}{ Telecommuter } & \multicolumn{2}{|c|}{ Older Adult } & \multicolumn{2}{|c|}{ Family with Children } \\
\hline & & $n$ & $\%$ & $n$ & $\%$ & $n$ & $\%$ & $n$ & $\%$ \\
\hline & Total (all) & 3085 & $100 \%$ & 1132 & $100 \%$ & 708 & $100 \%$ & 434 & $100 \%$ \\
\hline $1 \mathrm{~A}$ & Users of UGS & 1423 & $46 \%$ & 551 & $49 \%$ & 389 & $55 \%$ & 263 & $61 \%$ \\
\hline $1 \mathrm{~B}$ & New users of UGS & 300 & $10 \%$ & 141 & $12 \%$ & 62 & $9 \%$ & 50 & $12 \%$ \\
\hline $2 \mathrm{~A}$ & Small park user & 751 & $24 \%$ & 286 & $25 \%$ & 195 & $28 \%$ & 204 & $47 \%$ \\
\hline $2 B$ & Large park user & 594 & $19 \%$ & 260 & $23 \%$ & 162 & $23 \%$ & 131 & $30 \%$ \\
\hline $2 C$ & Greenway user & 926 & $30 \%$ & 371 & $33 \%$ & 240 & $34 \%$ & 150 & $35 \%$ \\
\hline $2 \mathrm{D}$ & Urban forest user & 260 & $8 \%$ & 102 & $9 \%$ & 92 & $13 \%$ & 47 & $11 \%$ \\
\hline $2 \mathrm{E}$ & Temple and/or shrine user & 283 & $9 \%$ & 125 & $11 \%$ & 77 & $11 \%$ & 38 & $9 \%$ \\
\hline \multirow[t]{2}{*}{$2 \mathrm{~F}$} & Urban farmland user & 65 & $2 \%$ & 40 & $4 \%$ & 11 & $2 \%$ & 12 & $3 \%$ \\
\hline & Total (users of UGS) & 1423 & $46 \%$ & 551 & $49 \%$ & 389 & $55 \%$ & 263 & $61 \%$ \\
\hline $3 \mathrm{~A}$ & Felt satisfied with UGS & 871 & $61 \%$ & 367 & $67 \%$ & 240 & $62 \%$ & 168 & $64 \%$ \\
\hline $3 B$ & Useful for stress relief & 863 & $61 \%$ & 358 & $65 \%$ & 230 & $59 \%$ & 159 & $60 \%$ \\
\hline $3 C$ & Reduced loneliness & 376 & $26 \%$ & 166 & $30 \%$ & 87 & $22 \%$ & 86 & $33 \%$ \\
\hline $3 \mathrm{D}$ & Felt a connection with others & 342 & $24 \%$ & 130 & $24 \%$ & 98 & $25 \%$ & 86 & $33 \%$ \\
\hline $3 \mathrm{E}$ & Distancing can be maintained & 945 & $66 \%$ & 349 & $63 \%$ & 311 & $80 \%$ & 168 & $64 \%$ \\
\hline $3 \mathrm{~F}$ & Able to use UGS without being self-conscious & 883 & $62 \%$ & 341 & $62 \%$ & 300 & $77 \%$ & 138 & $52 \%$ \\
\hline $3 G$ & Noticed nature in close proximity & 641 & $45 \%$ & 283 & $51 \%$ & 169 & $43 \%$ & 127 & $48 \%$ \\
\hline $3 \mathrm{H}$ & Noticed positive aspects of my neighborhood & 720 & $51 \%$ & 315 & $57 \%$ & 203 & $52 \%$ & 145 & $55 \%$ \\
\hline
\end{tabular}

Abbreviations: UGS, urban green space.

With regard to the respondents' evaluations and perceptions of UGS ( $n=1423), 61 \%$ of the users of UGS seemed to be satisfied with their exercise and rest in the UGS. In terms of the function of UGS, relatively more people (61\%) felt that UGS had a function of relieving anxiety and stress, while a lesser proportion of them were of the view that UGS could relieve loneliness $(26 \%)$ or help them feel connected to others $(24 \%)$. This may be due in part to the fact that people refrained from communicating when using UGS during the emergency period. Indeed, $66 \%$ of the respondents perceived that they were able to use the UGS while maintaining physical distance. Finally, as a result of using the UGS, $45 \%$ of the respondents became aware of the surrounding nature, and 51\% realized the goodness of the community.

\subsection{Model 1: Use of UGS}

The relationship between the use of UGS and user characteristics was analyzed using binomial logistic regression (Table 2). The results showed that telecommuters (odds ratio [OR] $=1.489, p<0.001)$, older adults $(\mathrm{OR}=1.824, p<0.001)$, and families with children $(\mathrm{OR}=2.329, p<0.001)$ often used UGS at a highly significant level (Model 1A). Other factors such as owning a dog $(\mathrm{OR}=1.639, p=0.001)$, being male $(\mathrm{OR}=1.165, p=0.051)$, and not working $(\mathrm{OR}=1.218, p=0.054)$ were also related to the use of UGS. In contrast to previous studies, living with someone or living in the suburbs was found to be unlikely to affect the use of UGS in Tokyo during the emergency period. Telecommuters $(\mathrm{OR}=1.535, p=0.004)$ 
and women $(\mathrm{OR}=1.815, p<0.001)$ were more likely to be new users of UGS during the emergency period (Model 1B). The odds ratio for telecommuters was larger than that for older adults and families with children, suggesting that the pandemic was an opportunity for them to commence the use of UGS. Additionally, based on the analysis that adjusted for the decreased worktime, the tendency of the new use of UGS by telecommuters was revealed. In other words, telecommuting may have accelerated the new use of UGS, regardless of whether work hours increased or decreased.

Table 2. Use of UGS and user characteristics (Model 1).

\begin{tabular}{|c|c|c|c|c|c|c|c|c|}
\hline & \multicolumn{4}{|c|}{ Model 1A } & \multicolumn{4}{|c|}{ Model 1B } \\
\hline & \multicolumn{4}{|c|}{ Users of UGS } & \multicolumn{4}{|c|}{ New Users of UGS } \\
\hline & \multirow{2}{*}{$\begin{array}{c}\begin{array}{c}\text { Odds } \\
\text { Ratio }\end{array} \\
0.427\end{array}$} & \multirow{2}{*}{$\begin{array}{c}\text { Std. } \\
\text { Error }\end{array}$} & \multicolumn{2}{|c|}{$p$-Value } & \multirow{2}{*}{$\begin{array}{l}\begin{array}{l}\text { Odds } \\
\text { Ratio }\end{array} \\
0.118\end{array}$} & \multirow{2}{*}{$\begin{array}{c}\text { Std. } \\
\text { Error }\end{array}$} & \multicolumn{2}{|c|}{$p$-Value } \\
\hline Intercept & & & 0.000 & $* * *$ & & & 0.000 & $* * *$ \\
\hline Telecommuter & 1.489 & 0.092 & 0.000 & $* * *$ & 1.535 & 0.148 & 0.004 & $* *$ \\
\hline Older adult & 1.824 & 0.104 & 0.000 & $* * *$ & 1.415 & 0.179 & 0.052 & \\
\hline Family with children & 2.329 & 0.114 & 0.000 & $* * *$ & 1.235 & 0.178 & 0.237 & \\
\hline Male & 1.165 & 0.078 & 0.051 & & 0.551 & 0.131 & 0.000 & $* * *$ \\
\hline Living with someone & 1.096 & 0.090 & 0.309 & & 0.939 & 0.148 & 0.669 & \\
\hline Dog owner & 1.639 & 0.155 & 0.001 & $* *$ & 0.523 & 0.333 & 0.052 & \\
\hline Living in suburbs & 1.057 & 0.075 & 0.457 & & 1.125 & 0.124 & 0.344 & \\
\hline Not worker & 1.218 & 0.102 & 0.054 & & 0.729 & 0.181 & 0.081 & \\
\hline Decreased worktime & 1.045 & 0.081 & 0.583 & & 1.088 & 0.131 & 0.521 & \\
\hline
\end{tabular}

Abbreviations: UGS, urban green space. ${ }^{*} p<0.05 ;{ }^{* *} p<0.01 ;{ }^{* *} p<0.001$.

\subsection{Model 2: Use of UGS Type}

The relationship between the use of the five types of UGS and user characteristics was analyzed using binomial logistic regression (Table 3). The results showed that telecommuters, older adults, and families with children commonly used large parks, greenways, and urban forests significantly more (Models 2B-D). Greenways for telecommuters $(\mathrm{OR}=1.541, p<0.001)$, large parks for families with children $(\mathrm{OR}=2.382, p<0.001)$, and urban forests for older adults $(\mathrm{OR}=1.888, p<0.001)$ had relatively large odds ratios. Furthermore, older adults $(\mathrm{OR}=1.563, p<0.001)$ and families with children (OR $=4.534, p<0.001)$ significantly used small parks more often, whereas telecommuters did not (Model 2A). In contrast, telecommuters significantly used temple and shrine areas more often $(\mathrm{OR}=1.699$, $p=0.001$ ), but older adults and families with children did not (Model 2E).

\subsection{Model 3: Evaluation of Use of UGS}

The relationship between the characteristics of users of UGS and their evaluations and perceptions of UGS was analyzed using binomial logistic regression (Table 4). First, telecommuters were found to be relatively satisfied with their use of UGS ( $\mathrm{OR}=1.448, p=0.005)$ (Model 3A). In addition, while more than $60 \%$ of UGS users during the emergency period appreciated the relief from anxiety and stress through using UGS, telecommuters were more likely to rate it $(\mathrm{OR}=1.259, p=0.082)$ (Model 3B). Next, older adults $(\mathrm{OR}=1.507, p=0.019)$ and families with children (OR $=1.895, p<0.001)$ commonly felt more connected to others by using UGS (Model 3D). In particular, older adults seemed to be able to use the UGS without worrying about others $(\mathrm{OR}=2.020, p<0.001)$ and keeping their distance from others $(\mathrm{OR}=2.176, p<0.001)$ (Models 3E and 3F). Families with children appeared to have appreciated the relief from loneliness made possible by their use of UGS (OR $=1.335, p=0.077)$ (Model 3C). Finally, telecommuters $(\mathrm{OR}=1.506, p=0.003$ ) and older adults $(\mathrm{OR}=1.570$, $p=0.003$ ) shared the tendency to feel that the use of the UGS provided them with an opportunity to become aware of the existence of the nature around them (Model 3G). In addition, telecommuters $(\mathrm{OR}=1.748, p<0.001)$ and older adults $(\mathrm{OR}=1.720, p<0.001)$ had a significantly better understanding of positive aspects of their neighborhoods through the use of UGS (Model 3H). 
Table 3. Use of UGS type and user characteristics (Model 2).

\begin{tabular}{|c|c|c|c|c|c|c|c|c|c|c|c|c|c|c|c|c|c|c|c|c|}
\hline & \multicolumn{4}{|c|}{ Model 2A } & \multicolumn{4}{|c|}{ Model 2B } & \multicolumn{4}{|c|}{ Model 2C } & \multicolumn{4}{|c|}{ Model 2D } & \multicolumn{4}{|c|}{ Model 2E } \\
\hline & \multicolumn{4}{|c|}{ Small Park } & \multicolumn{4}{|c|}{ Large Park } & \multicolumn{4}{|c|}{ Greenway } & \multicolumn{4}{|c|}{ Urban Forest } & \multicolumn{4}{|c|}{ Shrine and Temple } \\
\hline & \multirow{2}{*}{$\begin{array}{l}\text { Odds } \\
\text { Ratio }\end{array}$} & \multirow{2}{*}{$\begin{array}{c}\begin{array}{c}\text { Std. } \\
\text { Error }\end{array} \\
0.137\end{array}$} & \multicolumn{2}{|c|}{$p$-Value } & \multirow{2}{*}{$\begin{array}{c}\begin{array}{c}\text { Odds } \\
\text { Ratio }\end{array} \\
0.098\end{array}$} & \multirow{2}{*}{$\begin{array}{c}\begin{array}{c}\text { Std. } \\
\text { Error }\end{array} \\
0.155\end{array}$} & \multicolumn{2}{|c|}{$p$-Value } & \multirow{2}{*}{$\begin{array}{c}\begin{array}{c}\text { Odds } \\
\text { Ratio }\end{array} \\
0.229 \\
\end{array}$} & \multirow{2}{*}{$\begin{array}{c}\begin{array}{c}\text { Std. } \\
\text { Error }\end{array} \\
0.125\end{array}$} & \multicolumn{2}{|c|}{$p$-Value } & \multirow{2}{*}{$\begin{array}{c}\begin{array}{c}\text { Odds } \\
\text { Ratio }\end{array} \\
0.016\end{array}$} & \multirow{2}{*}{$\begin{array}{c}\begin{array}{c}\text { Std. } \\
\text { Error }\end{array} \\
0.248\end{array}$} & \multicolumn{2}{|c|}{$p$-Value } & \multirow{2}{*}{$\begin{array}{c}\begin{array}{c}\text { Odds } \\
\text { Ratio }\end{array} \\
0.061\end{array}$} & \multirow{2}{*}{$\begin{array}{c}\begin{array}{c}\text { Std. } \\
\text { Error }\end{array} \\
0.202\end{array}$} & \multicolumn{2}{|c|}{$p$-Value } \\
\hline Intercept & & & 0.000 & $* * *$ & & & 0.000 & $* * *$ & & & 0.000 & $* * *$ & & & 0.000 & $* * *$ & & & 0.000 & $* * *$ \\
\hline Telecommuter & 1.192 & 0.109 & 0.108 & & 1.713 & 0.118 & 0.000 & $* * *$ & 1.541 & 0.100 & 0.000 & $* * *$ & 1.554 & 0.173 & 0.011 & $*$ & 1.699 & 0.162 & 0.001 & $* *$ \\
\hline Older adult & 1.563 & 0.121 & 0.000 & $* * *$ & 1.589 & 0.130 & 0.000 & $* * *$ & 1.335 & 0.111 & 0.009 & $* *$ & 1.888 & 0.177 & 0.000 & $* * *$ & 1.243 & 0.172 & 0.207 & \\
\hline Family with children & 4.534 & 0.122 & 0.000 & $* * *$ & 2.382 & 0.130 & 0.000 & $* * *$ & 1.330 & 0.118 & 0.016 & * & 1.679 & 0.191 & 0.007 & ** & 1.022 & 0.196 & 0.914 & \\
\hline Male & 1.530 & 0.095 & 0.000 & $* * *$ & 1.437 & 0.101 & 0.000 & $* * *$ & 1.053 & 0.085 & 0.540 & & 1.812 & 0.151 & 0.000 & $* * *$ & 1.276 & 0.135 & 0.071 & \\
\hline Living with someone & 0.892 & 0.110 & 0.297 & & 1.271 & 0.122 & 0.050 & & 1.090 & 0.099 & 0.381 & & 1.318 & 0.182 & 0.130 & & 1.100 & 0.155 & 0.540 & \\
\hline Dog owner & 1.628 & 0.171 & 0.004 & $* *$ & 1.614 & 0.179 & 0.007 & $* *$ & 1.256 & 0.161 & 0.157 & & 1.018 & 0.276 & 0.949 & & 0.971 & 0.272 & 0.915 & \\
\hline Living in suburbs & 0.826 & 0.088 & 0.029 & $*$ & 0.834 & 0.094 & 0.054 & & 1.231 & 0.080 & 0.009 & $* *$ & 2.789 & 0.146 & 0.000 & $* * *$ & 0.735 & 0.128 & 0.016 & * \\
\hline Not worker & 1.155 & 0.121 & 0.236 & & 1.199 & 0.135 & 0.177 & & 1.308 & 0.111 & 0.016 & * & 1.240 & 0.191 & 0.260 & & 1.389 & 0.185 & 0.076 & \\
\hline Decreased worktime & 0.960 & 0.096 & 0.667 & & 1.089 & 0.102 & 0.402 & & 1.171 & 0.086 & 0.066 & & 1.076 & 0.147 & 0.619 & & 1.192 & 0.135 & 0.194 & \\
\hline
\end{tabular}

Abbreviations: UGS, urban green space. ${ }^{*} p<0.05$; ${ }^{* *} p<0.01$; ${ }^{* * *} p<0.001$.

Table 4. Evaluation of use of UGS and user characteristics (Model 3).

\begin{tabular}{|c|c|c|c|c|c|c|c|c|c|c|c|c|c|c|c|c|c|c|c|c|c|c|c|c|c|c|c|c|c|c|c|c|}
\hline \multirow[b]{4}{*}{ Intercept } & \multicolumn{4}{|c|}{ Model 3A } & \multicolumn{4}{|c|}{ Model 3B } & \multicolumn{4}{|c|}{ Model 3C } & \multicolumn{4}{|c|}{ Model 3D } & \multicolumn{4}{|c|}{ Model 3E } & \multicolumn{4}{|c|}{ Model 3F } & \multicolumn{4}{|c|}{ Model 3G } & \multicolumn{4}{|c|}{ Model 3H } \\
\hline & \multicolumn{4}{|c|}{ Felt Satisfied with UGS } & \multicolumn{4}{|c|}{ Useful for Stress Relief } & \multicolumn{4}{|c|}{ Reduced Loneliness } & \multicolumn{4}{|c|}{$\begin{array}{l}\text { Felt a Connection with } \\
\text { Others }\end{array}$} & \multicolumn{4}{|c|}{$\begin{array}{c}\text { Distancing Can Be } \\
\text { Maintained }\end{array}$} & \multicolumn{4}{|c|}{$\begin{array}{c}\text { Able to Use UGS without Being } \\
\text { Self-Conscious }\end{array}$} & \multicolumn{4}{|c|}{ Noticed Nature in Close Proximity } & \multicolumn{4}{|c|}{$\begin{array}{l}\text { Noticed Positive Aspects of my } \\
\text { Neighborhood }\end{array}$} \\
\hline & \multirow{2}{*}{$\begin{array}{l}\begin{array}{l}\text { Odds } \\
\text { Ra- } \\
\text { tio }\end{array} \\
0.912\end{array}$} & \multirow{2}{*}{$\begin{array}{l}\begin{array}{c}\text { Std. } \\
\text { Er- } \\
\text { ror }\end{array} \\
0.166\end{array}$} & \multicolumn{2}{|c|}{$p$-Value } & \multirow{2}{*}{$\begin{array}{l}\begin{array}{l}\text { Odds } \\
\text { Ra- } \\
\text { tio }\end{array} \\
1.366\end{array}$} & \multirow{2}{*}{$\begin{array}{l}\begin{array}{l}\text { Std. } \\
\text { Er- } \\
\text { ror }\end{array} \\
0.160\end{array}$} & \multicolumn{2}{|c|}{$p$-Value } & \multirow{2}{*}{$\begin{array}{l}\begin{array}{l}\text { Odds } \\
\text { Ra- } \\
\text { tio }\end{array} \\
0.374\end{array}$} & \multirow{2}{*}{$\begin{array}{l}\begin{array}{l}\text { Std. } \\
\text { Er- } \\
\text { ror }\end{array} \\
0.188\end{array}$} & \multicolumn{2}{|c|}{$p$-Value } & $\begin{array}{l}\text { Odds } \\
\text { Ra- } \\
\text { tio }\end{array}$ & $\begin{array}{c}\text { Std. } \\
\text { Er- } \\
\text { ror }\end{array}$ & $p-\mathrm{V}_{\mathrm{a}}$ & & $\begin{array}{l}\text { Odds } \\
\text { Ra- } \\
\text { tio }\end{array}$ & $\begin{array}{c}\text { Std. } \\
\text { Er- } \\
\text { ror }\end{array}$ & $p$-Val & & $\begin{array}{l}\text { Odds } \\
\text { Ra- } \\
\text { tio }\end{array}$ & $\begin{array}{c}\text { Std. } \\
\text { Er- } \\
\text { ror }\end{array}$ & $p-\mathrm{V}_{\mathrm{a}}$ & & $\begin{array}{l}\text { Odds } \\
\text { Ra- } \\
\text { tio }\end{array}$ & $\begin{array}{l}\text { Std. } \\
\text { Er- } \\
\text { ror }\end{array}$ & & & $\begin{array}{l}\text { Odds } \\
\text { Ra- } \\
\text { tio }\end{array}$ & $\begin{array}{c}\text { Std. } \\
\text { Er- } \\
\text { ror }\end{array}$ & $p-\mathrm{V}_{\mathrm{a}}$ & \\
\hline & & & 0.580 & & & & 0.060 & & & & 0.000 & $* * *$ & & 0.195 & 0.000 & $* * *$ & 1.067 & 0.169 & 0.702 & & 0.995 & 0.168 & 0.975 & & 0.917 & 0.169 & 0.607 & & 0.840 & 0.168 & 0.301 & \\
\hline Telecommuter & 1.448 & 0.133 & 0.005 & $* *$ & 1.259 & 0.132 & 0.082 & & 1.219 & 0.150 & 0.186 & & 0.940 & 0.158 & 0.696 & & 1.008 & 0.134 & 0.952 & & 1.153 & 0.134 & 0.285 & & 1.506 & 0.136 & 0.003 & $* *$ & 1.748 & 0.135 & 0.000 & $* * *$ \\
\hline Older adult & 1.184 & 0.147 & 0.251 & & 1.100 & 0.146 & 0.516 & & 1.055 & 0.173 & 0.757 & & 1.507 & 0.175 & 0.019 & * & 2.020 & 0.156 & 0.000 & $* * *$ & 2.176 & 0.154 & 0.000 & $* * *$ & 1.570 & 0.151 & 0.003 & $*$ & 1.720 & 0.149 & 0.000 & $* * *$ \\
\hline Family with children & 0.987 & 0.149 & 0.928 & & 0.830 & 0.148 & 0.210 & & 1.335 & 0.163 & 0.077 & & 1.895 & 0.169 & 0.000 & ${ }^{* * *}$ & 1.043 & 0.149 & 0.780 & & 0.845 & 0.148 & 0.255 & & 1.043 & 0.151 & 0.778 & & 1.131 & 0.149 & 0.408 & \\
\hline Male & 0.805 & 0.114 & 0.057 & & 0.660 & 0.114 & 0.000 & $* * *$ & 0.712 & 0.129 & 0.009 & ** & 0.783 & 0.135 & 0.070 & & 0.994 & 0.116 & 0.961 & & 1.143 & 0.114 & 0.241 & & 0.419 & 0.117 & 0.000 & $* * *$ & 0.470 & 0.116 & 0.000 & $* * *$ \\
\hline Dog owner & 0.629 & 0.200 & 0.021 & * & 0.714 & 0.200 & 0.092 & & 0.767 & 0.249 & 0.287 & & 0.812 & 0.258 & 0.420 & & 1.176 & 0.210 & 0.440 & & 1.329 & 0.209 & 0.172 & & 0.549 & 0.222 & 0.007 & $* *$ & 0.660 & 0.209 & 0.047 & * \\
\hline Living in suburbs & 1.296 & 0.105 & 0.014 & * & 0.979 & 0.105 & 0.836 & & 0.977 & 0.121 & 0.844 & & 0.793 & 0.125 & 0.064 & & 1.494 & 0.108 & 0.000 & $* * *$ & 1.419 & 0.107 & 0.001 & ** & 1.077 & 0.108 & 0.488 & & 0.957 & 0.106 & 0.678 & \\
\hline Not worker & 0.923 & 0.148 & 0.588 & & 0.871 & 0.148 & 0.353 & & 0.837 & 0.175 & 0.307 & & 0.868 & 0.177 & 0.423 & & 0.971 & 0.154 & 0.850 & & 0.863 & 0.152 & 0.334 & & 0.802 & 0.154 & 0.152 & & 0.991 & 0.151 & 0.952 & \\
\hline Decreased worktime & 0.956 & 0.116 & 0.698 & & 0.973 & 0.116 & 0.816 & & 1.102 & 0.131 & 0.456 & & 1.020 & 0.138 & 0.886 & & 0.734 & 0.117 & 0.008 & ** & 0.719 & 0.116 & 0.005 & ** & 1.162 & 0.118 & 0.203 & & 1.144 & 0.117 & 0.249 & \\
\hline
\end{tabular}




\section{Discussion}

\subsection{Use of UGS during the Pandemic}

This study revealed that $46 \%$ of the respondents used UGS during the first wave of the COVID-19 pandemic in Tokyo. Given that $88 \%$ of respondents used them in Brisbane [13], the use of UGS in Tokyo was relatively low. This difference may be due to the fact that the per capita park area in Tokyo is smaller than in Brisbane [44,48], and consequently the habit of using UGS on a daily basis is less popular.

Focusing on the perceptions by users of UGS, the results showed that relatively more people valued stress relief and fewer people valued human connection during the pandemic. This suggests that mental health may have improved through the use of UGS, while social health may have been less likely to improve. These results are in common with the findings of the Brisbane study by Berdejo-Espinola et al. (2021) [13]. However, Xie (2020) concluded that the users of UGS satisfied their social interaction needs in Chengdu [35]. Berdejo-Espinola et al. (2021) explains this difference as being due to the strictness of behavioral restrictions; in Brisbane, the restriction that only one person from the same household could go out is stricter than in Chengdu. Tokyo's behavioral restrictions are not as strict as Brisbane's, but rather similar to Chengdu's [41,43]. Therefore, not only factors related to the COVID-19 pandemic, but also cultural differences in the use of UGS may have influenced the results.

Although the number of users of UGS in Tokyo is small compared to those in other countries, the use of UGS still has a positive effect on the users. Considering the health benefits of UGS, it is worthwhile to open privately owned UGS as well, in case similar restrictions on behavior are required in the future.

\subsection{Characteristics of Users of UGS during the Pandemic}

This study reveals who used UGS frequently during the first wave of COVID-19 in Tokyo, Japan. Telecommuters, older adults, and families with children were each significantly correlated with the use of UGS (Model 1A). Telecommuters were significantly correlated with new use of UGS, while older adults and families with children were not significantly correlated (Model 1B). The drastic change in work styles associated with the pandemic may have consequently triggered the use of UGS by telecommuters.

Telecommuters will need to be rethought of as new users of UGS. Several prepandemic studies have discussed the relationship between life stage and the use of UGS [30], and it has been found that age [25,31] and the presence of having children [26-28] strongly influence the use of UGS. The results of this study for Tokyo during the emergency period also showed that the older adults and families with children frequently used UGS. The relationship between work style and UGS use has only been discussed by Boyd et al. (2018) [29], who conducted interviews with individuals regarding their reasons for not using UGS in England, and they found that the most common response was because they were "too busy at work". However, in this study of Tokyo during the emergency period, there was no correlation between decreased time at work and the use of UGS. Independent of the decrease in time spent working, there was a significant correlation between telecommuters and the use of UGS (Model 1A). Even if workers believe that they do not use UGS because they are too busy working, it does not seem likely that they will use UGS if their work hours simply decrease. Whether workers use UGS or not is not only influenced by the time they work but also by their work style.

Telecommuters appear to have a different preference for UGS compared to those who had been frequent users of UGS continuously before the pandemic. For example, there is a significant positive correlation between telecommuters and the use of temple and shrine land, but no significant correlation between older adults and families with children (Model 2E). Meanwhile, older adults and families with children have a significant positive correlation with the use of small parks, but there is no significant correlation among telecommuters (Model 2A). Older adults and families with children significantly felt a connection to others through the use of UGS, but there is no significant correlation for 
telecommuters (Model 3D). Telecommuters may have avoided small parks crowded and instead used shrines and temples where they could spend time more quietly.

\subsection{Post-COVID-19 Planning for UGS}

The answer to the question of who uses UGS frequently is not a fixed one determined by life stage, but should be seen as a dynamic one that changes with time and social conditions. Several studies have identified the characteristics of users of UGS [23,24]. However, telecommuters, who are the focus of this study as users of UGS, engage in a new work style made possible by the development of information and communications technology. In addition, the COVID-19 pandemic led many companies to introduce telecommuting systems [49]. Therefore, the use of UGS by telecommuters can be regarded as part of a new-age lifestyle.

If city planners assume that the users of UGS will change due to technological development and social conditions, then future UGS planning should incorporate a perspective of responding to change. Conventional UGS planning in general has aimed to identify the image of the users of UGS and to develop UGS that are comfortable for that target. However, if the user base changes as society changes, as this study shows, the preference for UGS can also change. With this in mind, it would be desirable for city planners to renovate UGS in response to changes in users in the short term, and in the long term, to aim for a state in which a wide variety of UGS are available to residents so that they can respond to changes in the user base.

In the wake of the pandemic, it is important to design and manage UGS that consider the characteristics of telecommuters. The introduction of telecommuting systems by companies during the COVID-19 pandemic was an effective option to continue business activities while protecting employees from infection risks [50]. However, some studies have shown that telecommuters during the pandemic were at a higher risk of decreased psychological well-being than those who commuted [51]. While telecommuters were more likely to be at risk for health risks, they may have used UGS to improve their health status. The results of this study showed that telecommuters who used UGS tended to feel that their anxiety and stress were alleviated (Model 3B). If telecommuters are considered to have been important supporters of economic activities during the pandemic, it is necessary to discuss how UGS can be effective in reducing their health risks. For example, small parks in neighborhood are basically designed for children and/or older adults and playground equipment and health devices are installed. However, considering the results of this study, it is worthwhile to take other design options into account, such as planting more trees and creating a quiet atmosphere for stress-relief.

In recent years, there has been an accelerating movement around the world to make a wide variety of open spaces available to citizens. In Japan, for example, a system has been established to encourage companies to renovate parks and to make privately owned vacant land available to citizens [52]. Since it is difficult for governments to purchase land to build parks in urban areas where land prices are high, it is desirable to encourage residents to make a wide variety of UGS available to them by skillfully handling various systems.

\subsection{Limitations}

This was a case study in one Asian megacity, even though it covered both high-density urban centers and low-density suburbs. Therefore, the results are likely to be influenced by the insufficient amount of green space in Tokyo and the cultural background of Japanese people's use of UGS. To clarify the characteristics of UGS users in more generic emergencies, comparisons with other cities are important.

The use of internet-based data collection tools can lead to a bias that participants who voluntarily register with the research company are not representative of adults living in Tokyo. However, considering the special circumstances of a pandemic, it was concluded that an online survey was the safest and most reliable method. 
This questionnaire survey was conducted in June 2020, immediately after the pandemic was initially announced; this was a time of drastic change in lifestyle, and it will be necessary to determine whether this change is transitory or whether it is something that should be studied for UGS planning in the post-COVID-19 society. Thus, it will be important to compare the results of this study with the results of surveys conducted in the future when more time has passed.

\section{Conclusions}

The results of this study contribute to the characterization of UGS users during the COVID-19 pandemic. An online questionnaire survey of Tokyo residents was conducted to determine whether or not urban residents used UGS, whether or not they used five particular types of UGS, and their evaluation and perception of UGS. A logistic regression analysis was conducted to examine the relationship between the results and the characteristics of the users. The results showed that telecommuters, older adults, and families with children were significantly more likely to use UGS. In addition to the relationship between life stage and UGS use, which has been frequently pointed out in past studies, this study found a correlation between work style and UGS use. This is thought to be a new relationship that was found due to the drastic change in work styles caused by the pandemic. In addition, the preference of telecommuters seems to be different from the preference of older adults and families with children for UGS. Telecommuters do not use small parks significantly as often as older adults and families with children. In addition, telecommuters do not tend to feel connected to other people through the use of UGS as older adults and families with children do. In contrast, telecommuters visit temple and shrine grounds significantly more often, have a higher overall satisfaction with the use of UGS, and appreciate their stress-relieving functions. There were also commonalities such as significantly more frequent use of large parks, greenways, and urban forests. An important finding is that social impacts, such as pandemics, can lead to drastic changes in lifestyle, which in turn can change the users of UGS and their purposes of using UGS.

Author Contributions: Conceptualization, T.Y., A.I. and M.Y.; methodology, T.Y. and A.I.; software, T.Y.; validation, T.Y., A.I. and K.H.; formal analysis, T.Y.; investigation, T.Y., A.I., K.H., A.M., U.H., H.K. and T.T.; data curation, T.Y.; writing-original draft preparation, T.Y.; writing-review and editing, T.Y., K.H., U.H. and M.Y.; visualization, T.Y.; supervision, M.Y.; project administration, T.Y. and M.Y.; funding acquisition, A.I., T.T. and M.Y. All authors have read and agreed to the published version of the manuscript.

Funding: This research was supported by the Tokyo Metropolitan Government and JSPS KAKENHI, grant number 19K15863, 19H02984, 18H01602, 19K15863, and 21K14311.

Institutional Review Board Statement: The study protocol was approved by the Ethical Committee of School of Engineering, The University of Tokyo (approval number KE20-8, 8 June 2020).

Informed Consent Statement: Informed consent was obtained from all subjects involved in the study.

Data Availability Statement: The data that support the findings of this study are available from the corresponding author, T.Y., upon reasonable request.

Conflicts of Interest: The authors declare no conflict of interest. 


\section{Appendix A}

Table A1. Explanation of the study models.

\begin{tabular}{|c|c|c|}
\hline Model & Questionnaire & Explanation of the Objective Variable \\
\hline $\begin{array}{l}\text { Model } 1 \\
\text { Use of } \\
\text { UGS/Binary } \\
\text { variable }\end{array}$ & $\begin{array}{l}\text { Question: "How often did you use } \\
\text { UGS during the declaration of the } \\
\text { state of emergency?" and "How did } \\
\text { the frequency of your use of UGS } \\
\text { change during the declaration of the } \\
\text { state of emergency compared to } \\
\text { before?" }\end{array}$ & $\begin{array}{l}\text { - 1A "user of UGS"; Respondents who use UGS "several times a } \\
\text { month," "once or twice a week," "three or four times a week," or } \\
\text { "almost every day." } \\
\text { - 1B "New user of UGS"; Change in frequency of use of UGS: "No use } \\
\text { before, used for the first time/after a long time during the emergency } \\
\text { period." }\end{array}$ \\
\hline
\end{tabular}

- 2A "Small Park"; Respondents who use a small park/ plaza (with some playground equipment and benches) "several times a month," "once or twice a week," "three or four times a week," or "almost every day."

- 2B "Large Park"; Respondents who use large parks and squares

Model 2

Availability of

UGS by type of use/Binary

variable
Question: "How often did you use the following UGS (small park/large park/greenway/urban forest/temple/shrine) during the period when the state of emergency was declared?"
Model 3

Evaluation and recognition of

the use of

UGS/Binary variable
Question to be answered only by users of UGS: "During the period of the declaration of a state of emergency, how did you feel when you used UGS?" (sports facilities and large open spaces of some size) "several times a month," "once or twice a week," "three or four times a week," or "almost every day."

- 2C "Greenway"; Respondents who use greenways, riverbeds, and riverside paths "several times a month," "once or twice a week," "three or four times a week," or "almost every day."

- 2D "Urban Forest"; Respondents who use woodlands and thickets "several times a month," "once or twice a week," "three or four times a week," or "almost every day."

- 2E "Temple and Shrine"; Respondents who use precincts of temples and shrines "several times a month," "once or twice a week," "three or four times a week," or "almost every day."

- 3A "Felt satisfied with UGS"; Responded "very much agree" or "agree" to the question "I was satisfied with exercising or resting in an urban green space."

- 3B "Useful for stress relief"; Responded "very much agree" or "agree" to the question "I felt relieved of anxiety and stress."

- 3C "Reduced loneliness"; Responded "very much agree" or "agree" to the question "I felt less lonely."

- 3D "Felt a connection with others"; Responded "very much agree" or "agree" to the question "I felt connected to others in a relaxed way."

- 3E "Distancing can be maintained"; Responded "very much agree" or "agree" to the question "I was able to maintain a sufficient physical distance in the park green space."

- 3F "Able to use UGS without being self-conscious"; Responded "very much agree" or "agree" to the question "I was able to use the UGS without worrying about the eyes around me."

- 3G "Noticed nature in close proximity"; Responded "very much agree" or "agree" to the question "It was an opportunity for me to become aware of the existence of nature around me that I had not noticed before."

- 3H "Noticed positive aspects of my neighborhood"; Responded "very much agree" or "agree" to the question "It was an opportunity for me to become aware of the good qualities of the area where I live." 


\section{Appendix B}

Table A2. Relationship between use of UGS and personal attributes.

\begin{tabular}{|c|c|c|}
\hline Author(s) and Year of Publication & Target and Sample Size & Association(s) \\
\hline Jim and Chen, 2006 [27] & $\begin{array}{l}\text { Guangzhou, China; } \\
\qquad N=340\end{array}$ & older adults, group use, with children \\
\hline Sanesi and Chiarello, 2006 [30] & $\begin{array}{l}\text { Bari, Italy; } \\
\mathrm{N}=230\end{array}$ & suburban residents, $25-44$ years old, married \\
\hline Wong, 2009 [28] & $\begin{array}{l}\text { Hong Kong, China; } \\
\qquad \mathrm{N}=758\end{array}$ & over 60 years old, married, with children \\
\hline Schipperijn et al., 2010a [25] & $\begin{array}{l}\text { Denmark; } \\
\mathrm{N}=21,832\end{array}$ & $\begin{array}{c}\text { elderly males, more years of education, ethnic } \\
\text { Danes }\end{array}$ \\
\hline Schipperijn et al., 2010b [26] & $\begin{array}{l}\text { Odense, Denmark; } \\
\quad \mathrm{N}=1305\end{array}$ & $\begin{array}{c}\text { with children under } 6 \text { years old, dog owners, } \\
\text { older adults }\end{array}$ \\
\hline Wendel et al., 2012 [32] & $\begin{array}{l}\text { Santa Cruz, Bolivia; } \\
\qquad \mathrm{N}=281\end{array}$ & 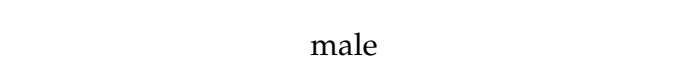 \\
\hline Sang et al., 2016 [33] & $\begin{array}{l}\text { Gothenburg, Sweden; } \\
\qquad \mathrm{N}=1347\end{array}$ & female \\
\hline Sreetheran, 2017 [31] & $\begin{array}{l}\text { Kuala Lumpur, Malaysia; } \\
\qquad N=669\end{array}$ & young adults $*$, group use $*$ \\
\hline Boyd et al., 2018 [29] & $\begin{array}{l}\text { England; } \\
\mathrm{N}=63,891\end{array}$ & $\begin{array}{l}\text { male, young, Caucasian, non-full-time worker, } \\
\text { married or cohabiting, with children, dog owner }\end{array}$ \\
\hline
\end{tabular}

\section{Appendix C}

Table A3. Details of the explanatory variables.

\begin{tabular}{|c|c|c|c|}
\hline Variable & Respondents & Description & Reference(s) \\
\hline Telecommuter & $1132(37 \%)$ & $\begin{array}{l}\text { Work style during the } \\
\text { emergency period is } \\
\text { telecommuting at least one } \\
\text { day a week. }\end{array}$ & \\
\hline Older Adult & $708(23 \%)$ & Age is 65 years or older & $\begin{array}{c}\text { Schipperijn et al., 2010a [23]; } \\
\text { Schipperijn et al., 2010b [26]; Jim and } \\
\text { Chen, 2006 [27]; Wong, 2009 [28] }\end{array}$ \\
\hline Family with Children & $434(14 \%)$ & $\begin{array}{l}\text { Age between } 20 \text { and } 45 \text { years } \\
\text { old, and living with children }\end{array}$ & $\begin{array}{l}\text { Schipperijn et al., 2010b [26]; Jim and } \\
\text { Chen, } 2006 \text { [27]; Wong, 2009 [28]; } \\
\text { Boyd et al. 2018 [29] }\end{array}$ \\
\hline Man & $1647(53 \%)$ & The gender is male & $\begin{array}{l}\text { Boyd et al., } 2018 \text { [29]; Wendel et al., } \\
2012 \text { [32] }\end{array}$ \\
\hline Living with Someone & $2329(75 \%)$ & Except for single occupants & $\begin{array}{l}\text { Wong, } 2009 \text { [28]; Boyd et al., } 2018 \text { [29]; } \\
\text { Sanesi and Chiarello, } 2006 \text { [30] }\end{array}$ \\
\hline Dog Owner & $188(6 \%)$ & Living with a dog & Schipperijn et al., 2010b [26] \\
\hline Living in Suburbs & $1541(50 \%)$ & $\begin{array}{l}\text { Selecting the Tama suburbs as } \\
\text { their residence }\end{array}$ & Sanesi and Chiarello, 2006 [30] \\
\hline Not Worker & $1011(33 \%)$ & $\begin{array}{l}\text { Not working during the } \\
\text { emergency period }\end{array}$ & Boyd et al., 2018 [29] \\
\hline Decreased worktime & $980(32 \%)$ & $\begin{array}{l}\text { Slight decrease or decrease in } \\
\text { work hours during the } \\
\text { emergency period. }\end{array}$ & \\
\hline
\end{tabular}




\section{Appendix D}

Table A4. Telecommuting experience.

\begin{tabular}{ccc}
\hline & & Total \\
\hline Total (all telecommuters) & $n$ & $\%$ \\
\hline Telecommuting since before the pandemic & 1132 & $100 \%$ \\
Start telecommuting during the pandemic & 110 & $10 \%$ \\
Telecommuting almost every day & 1022 & $90 \%$ \\
Telecommuting up to one day per week & 686 & $61 \%$ \\
\hline
\end{tabular}

\section{References}

1. World Health Organization. Statement on the Second Meeting of the International Health Regulations (2005) Emergency Committee Regarding the Outbreak of Novel Coronavirus (2019-nCoV). 2020. Available online: https://www.who.int/ news/ item/30-01-2020-statement-on-the-second-meeting-of-the-international-health-regulations-(2005)-emergency-committeeregarding-the-outbreak-of-novel-coronavirus-(2019-ncov) (accessed on 24 June 2021).

2. Hale, T.; Angrist, N.; Cameron-Blake, E.; Hallas, L.; Kira, B.; Majumdar, S.; Petherick, A.; Phillips, T.; Tatlow, H.; Webster, S. Variation in Government Responses to COVID-19, Version 7.0. Blavatnik School of Government Working Paper. 25 May 2020. Available online: www.bsg.ox.ac.uk/covidtracker (accessed on 27 July 2021).

3. Tokyo Metropolitan Government. Message to the People of Tokyo: Refrain from Going Out at Night (Message from the Governor). Available online: https://www.metro.tokyo.lg.jp/english/governor/act/2020/0206_00.html (accessed on 24 June 2021).

4. Karako, K.; Song, P.; Chen, Y.; Tang, W. Shifting workstyle to teleworking as a new normal in face of COVID-19: Analysis with the model introducing intercity movement and behavioral pattern. Ann. Transl. Med. 2020, 8, 1056. [CrossRef] [PubMed]

5. Organisation for Economic Co-Operation and Development. Work-Life Balance. Available online: http://www.oecdbetterlifeindex. org/topics/work-life-balance (accessed on 24 June 2021).

6. Tokyo Metropolitan Government. Results of the Urgent Survey about Telework Introduction Rate. 2020. Available online: https: / / www.metro.tokyo.lg.jp/tosei/hodohappyo/press/2020/05/12/10.html (accessed on 24 June 2021).

7. United Nations, Department of Economic and Social Affairs, Population Division. World Population Ageing 2019: Highlights (ST/ESA/SER.A/430). 2019. Available online: https://www.un.org/en/development/desa/population/publications/pdf/ ageing/WorldPopulationAgeing2019-Highlights.pdf (accessed on 30 August 2021).

8. Verity, R.; Okell, L.C.; Dorigatti, I.; Winskill, P.; Whittaker, C.; Imai, N.; Cuomo-Dannenburg, G.; Thompson, H.; Walker, P.G.T.; Fu, H.; et al. Estimates of the severity of coronavirus disease 2019: A model-based analysis. Lancet Infect. Dis. 2020, 20, 669-677. [CrossRef]

9. Ritchie, H.; Mathieu, E.; Rodés-Guirao, L.; Appel, C.; Giattino, C.; Ortiz-Ospina, E.; Hasell, J.; Macdonald, B.; Beltekian, D.; Roser, M. Coronavirus Pandemic (COVID-19), Our World in Data. 2020. Available online: https:// ourworldindata.org/coronavirus (accessed on 24 August 2021).

10. Venter, Z.S.; Barton, D.N.; Gundersen, V.; Figari, H.; Nowell, M. Urban nature in a time of crisis: Recreational use of green space increases during the COVID-19 outbreak in Oslo, Norway. Environ. Res. Lett. 2020, 15, 104075. [CrossRef]

11. Geng, D.C.; Innes, J.; Wu, W.; Wang, G. Impacts of COVID-19 pandemic on urban park visitation: A global analysis. J. For. Res. 2021, 32, 553-567. [CrossRef]

12. Pérez-Urrestarazu, L.; Kaltsidi, M.P.; Nektarios, P.A.; Markakis, G.; Loges, V.; Perini, K.; Fernández-Cañero, R. Particularities of having plants at home during the confinement due to the COVID-19 pandemic. Urban For. Urban Green. 2021, 59, 126919. [CrossRef]

13. Berdejo-Espinola, V.; Suárez-Castro, A.F.; Amano, T.; Fielding, K.S.; Oh, R.R.Y.; Fuller, R.A. Urban green space use during a time of stress: A case study during the COVID-19 pandemic in brisbane. People Nat. Hoboken 2021, 3, 597-609. [CrossRef]

14. Takano, T.; Nakamura, K.; Watanabe, M. Urban residential environments and senior citizens' longevity in megacity areas: The importance of walkable green spaces. J. Epidemiol. Commun. Health 2002, 56, 913-918. [CrossRef] [PubMed]

15. Thompson, C.W.; Roe, J.; Aspinall, P.; Mitchell, R.; Clow, A.; Miller, D. More green space is linked to less stress in deprived communities: Evidence from salivary cortisol patterns. Landsc. Urban Plan. 2012, 105, 221-229. [CrossRef]

16. Kardan, O.; Gozdyra, P.; Misic, B.; Moola, F.; Palmer, L.J.; Paus, T.; Berman, M.G. Neighborhood greenspace and health in a large urban center. Sci. Rep. 2015, 5, 11610. [CrossRef]

17. Cox, D.T.C.; Shanahan, D.F.; Hudson, H.L.; Plummer, K.E.; Siriwardena, G.M.; Fuller, R.A.; Anderson, K.; Hancock, S.; Gaston, K.J. Doses of neighborhood nature: The benefits for mental health of living with nature. Bioscience 2017, 67, 147-155. [CrossRef]

18. Lafortezza, R.; Carrus, G.; Sanesi, G.; Davies, C. Benefits and well-being perceived by people visiting green spaces in periods of heat stress. Urban For. Urban Green. 2009, 8, 97-108. [CrossRef]

19. Korpela, K.; Borodulin, K.; Neuvonen, M.; Paronen, O.; Tyrväinen, L. Analyzing the mediators between nature-based outdoor recreation and emotional well-being. J. Environ. Psychol. 2014, 37, 1-7. [CrossRef] 
20. Grilli, G.; Mohan, G.; Curtis, J. Public park attributes, park visits, and associated health status. Landsc. Urban Plan. 2020, 199, 103814. [CrossRef]

21. Shanahan, D.F.; Bush, R.; Gaston, K.J.; Lin, B.B.; Dean, J.; Barber, E.; Fuller, R.A. Health benefits from nature experiences depend on dose. Sci. Rep. 2016, 6, 28551. [CrossRef]

22. Bedimo-Rung, A.L.; Mowen, A.J.; Cohen, D.A. The significance of parks to physical activity and public health: A conceptual model. Am. J. Prev. Med. 2005, 28, 159-168. [CrossRef]

23. Kaczynski, A.T.; Henderson, K.A. Environmental correlates of physical activity: A review of evidence about parks and recreation. Leis. Sci. 2007, 29, 315-354. [CrossRef]

24. Kloek, M.E.; Buijs, A.E.; Boersema, J.J.; Schouten, M.G. Crossing borders: Review of concepts and approaches in research on greenspace, immigration and society in Northwest European countries. Landsc. Res. 2013, 38, 117-140. [CrossRef]

25. Schipperijn, J.; Ekholm, O.; Stigsdotter, U.K.; Toftager, M.; Bentsen, P.; Kamper-Jørgensen, F.; Randrup, T.B. Factors influencing the use of green space: Results from a danish national representative survey. Landsc. Urban Plan. 2010, 95, 130-137. [CrossRef]

26. Schipperijn, J.; Stigsdotter, U.K.; Randrup, T.B.; Troelsen, J. Influences on the use of urban green space-A case study in odense, denmark. Urban For. Urban Green. 2010, 9, 25-32. [CrossRef]

27. Jim, C.Y.; Chen, W.Y. Recreation-amenity use and contingent valuation of urban greenspaces in Guangzhou, China. Landsc. Urban Plan. 2006, 75, 81-96. [CrossRef]

28. Wong, K.K. Urban park visiting habits and leisure activities of residents in Hong Kong, China. Manag. Leis. 2006, 14, 125-140. [CrossRef]

29. Boyd, F.; White, M.P.; Bell, S.L.; Burt, J. Who doesn't visit natural environments for recreation and why: A population representative analysis of spatial, individual and temporal factors among adults in England. Landsc. Urban Plan. 2018, 175, 102-113. [CrossRef]

30. Sanesi, G.; Chiarello, F. Residents and urban green spaces: The case of bari. Urban For. Urban Green. 2006, 4, 125-134. [CrossRef]

31. Sreetheran, M. Exploring the urban park use, preference and behaviours among the residents of kuala lumpur, malaysia. Urban For. Urban Green. 2017, 25, 85-93. [CrossRef]

32. Wendel, H.E.W.; Zarger, R.K.; Mihelcic, J.R. Accessibility and usability: Green space preferences, perceptions, and barriers in a rapidly urbanizing city in Latin America. Landsc. Urban Plan. 2012, 107, 272-282. [CrossRef]

33. Sang, Å.O.; Knez, I.; Gunnarsson, B.; Hedblom, M. The effects of naturalness, gender, and age on how urban green space is perceived and used. Urban For. Urban Green. 2016, 18, 268-276. [CrossRef]

34. Ugolini, F.; Massetti, L.; Calaza-Martínez, P.; Cariñanos, P.; Dobbs, C.; Ostoić, S.K.; Marin, A.M.; Pearlmutter, D.; Saaroni, H.; Šaulienè, I.; et al. Effects of the COVID-19 pandemic on the use and perceptions of urban green space: An international exploratory study. Urban For. Urban Green. 2020, 56, 126888. [CrossRef] [PubMed]

35. Xie, J.; Luo, S.; Furuya, K.; Sun, D. Urban parks as green buffers during the COVID-19 pandemic. Sustainability 2020, $12,6751$. [CrossRef]

36. Huerta, C.M.; Utomo, A. Evaluating the association between urban green spaces and subjective well-being in mexico city during the COVID-19 pandemic. Health Place 2021, 70, 102606. [CrossRef]

37. Poortinga, W.; Bird, N.; Hallingberg, B.; Phillips, R.; Williams, D. The role of perceived public and private green space in subjective health and wellbeing during and after the first peak of the COVID-19 outbreak. Landsc. Urban Plan. 2021, 211, 104092. [CrossRef]

38. Lu, Y.; Zhao, J.; Wu, X.; Lo, S.M. Escaping to nature during a pandemic: A natural experiment in asian cities during the COVID-19 pandemic with big social media data. Sci. Total Environ. 2021, 777, 146092. [CrossRef]

39. Soga, M.; Evans, M.J.; Tsuchiya, K.; Fukano, Y. A room with a green view: The importance of nearby nature for mental health during the COVID-19 pandemic. Ecol. Appl. 2020, 31, e2248. [CrossRef] [PubMed]

40. Hino, K.; Asami, Y. Change in walking steps and association with built environments during the COVID-19 state of emergency: A longitudinal comparison with the first half of 2019 in Yokohama, Japan. Health Place 2021. [CrossRef]

41. Tashiro, A.; Shaw, R. COVID-19 pandemic response in Japan: What is behind the initial flattening of the curve? Sustainability 2020, 12, 5250. [CrossRef]

42. Cabinet Secretariat, Government of Japan. About the New Influenza Special Measures Act, COVID-19 Information and Resources. Available online: https://corona.go.jp/news/news_20200405_19.html (accessed on 30 June 2021).

43. Hale, T.; Webster, S. Oxford Covid-19 Government Response Tracker; Blavatnik School of Government, University of Oxford: Oxford, UK, 2020.

44. Breau of Construction, Tokyo Metropolitan Government. Parks in Tokyo. Available online: https://www.kensetsu.metro.tokyo. lg.jp/english/jigyo/park/01.html (accessed on 30 June 2021).

45. Agency for Cultural Affairs, Government of Japan. Religious Statistics Database 2020. Available online: https://www.bunka.go. jp/tokei_hakusho_shuppan/tokeichosa/shumu/index.html (accessed on 3 August 2021).

46. Breau of Construction, Tokyo Metropolitan Government. Urban Green Space Database 2020. Available online: https://www. kensetsu.metro.tokyo.lg.jp/content/000049137.pdf (accessed on 30 June 2021).

47. Peduzzi, P.; Concato, J.; Kemper, E.; Holford, T.R.; Feinstein, A.R. A simulation study of the number of events per variable in logistic regression analysis. J. Clin. Epidemiol. 1996, 49, 1373-1379. [CrossRef]

48. Rupprecht, C.D.D.; Byrne, J.A. Informal urban green-space: Comparison of quantity and characteristics in Brisbane, Australia and Sapporo, Japan. PLoS ONE 2014, 9, e99784. [CrossRef] [PubMed] 
49. Eurofound. Living, Working and COVID-19 Dataset, Dublin. Available online: http:/ / eurofound.link/covid19data (accessed on 30 June 2021).

50. Belzunegui-Eraso, A.; Erro-Garcés, A. Teleworking in the context of the Covid-19 crisis. Sustainability 2020, 12, 3662. [CrossRef]

51. Escudero-Castillo, I.; Mato-Díaz, F.J.; Rodriguez-Alvarez, A. Furloughs, teleworking and other work situations during the COVID-19 lockdown: Impact on mental well-being. Int. J. Environ. Res. Public Health 2021, 18, 2898. [CrossRef]

52. Ministry of Land, Infrastructure, Transport and Tourism, Government of Japan. Present Systems and Projects about Parks and Green Spaces. Available online: https:/ / www.mlit.go.jp/common/000996962.pdf (accessed on 30 June 2021). 